\title{
Hypertriglyceridaemia as a risk factor of coronary heart disease mortality in subjects with impaired glucose tolerance or diabetes
}

\author{
Results from the 11-year follow-up of the Paris Prospective Study
}

\author{
A. Fontbonne ${ }^{1}$, E. Eschwège ${ }^{1}$, F.Cambien ${ }^{2}$, J.-L. Richard ${ }^{2}$, P. Ducimetière ${ }^{2}$, N. Thibult ${ }^{1}$, J.-M. Warnet ${ }^{3}$, \\ J.-R.Claude ${ }^{3}$ and G.-E. Rosselin ${ }^{4}$ \\ ${ }^{1}$ INSERM Unité 21, Villejuif, ${ }^{2}$ INSERM Unité 258, Paris, \\ ${ }^{3}$ Laboratoire de Recherche de la Direction de l'Action Sociale, de l'Enfance et de la Santé, Paris and ${ }^{4}$ INSERM Unité 55 , Paris, France
}

\begin{abstract}
Summary. The Paris Prospective Study is a long-term investigation of the incidence of coronary heart disease in a large population of working men. The first follow-up examination involved 7,038 men, aged 43-54 years. Subjects with impaired glucose tolerance or diabetes $(n=943)$ were selected from the total population for a separate analysis of coronary heart disease mortality risk factors. During a mean follow-up of 11 years, 26 of these 943 subjects with abnormal glucose tolerance died from coronary heart disease. Univariate analysis showed that plasma triglyceride level $(p<0.006)$, plasma cholesterol level $(p<0.02)$, and plasma insulin level both fasting and 2 -h post-glucose load $(p<0.02)$, were significantly higher in subjects who died from coronary heart disease compared to those who did not. In multivariate regression analysis using the Cox model, plasma triglyceride level was the only factor
\end{abstract}

positively and significantly associated with coronary death. The distribution of plasma triglyceride levels was clearly higher for the subjects who died from coronary heart disease compared to those who did not die from this cause or were alive at the end of the follow-up. This new epidemiological evidence that hypertriglyceridaemia is an important predictor of coronary heart disease mortality in subjects with impaired glucose tolerance or diabetes suggests a possible role of dyslipidaemia in the excessive occurrence of atherosclerotic vascular disease in this category of subjects.

Key words: Epidemiology, risk factors, coronary heart disease mortality, diabetes, impaired glucose tolerance, plasma insulin level, plasma triglyceride level.
Diabetic subjects are known to have a high frequency of atherosclerosis [1], but the underlying mechanism remains unclear. Hyperglycaemia, on which the definition of the disease is based [2], may well not be a direct determinant of the atherosclerotic lesions of diabetes, since the incidence of cardiovascular events in diabetic subjects is not strictly related to the duration of hyperglycaemia $[3,4]$. Furthermore, three large prospective surveys on the risk factors of coronary heart disease, independently initiated in the late sixties in Finland [5], Australia [6] and France [7, 8], showed, after 5 to 10 years follow-up, that high insulin levels in healthy men were predictive of coronary heart disease (CHD), even after adjustment for the classical risk factors (age, blood pressure, smoking habits, plasma cholesterol), whereas hyperglycaemia and diabetes were not independent predictors. Many studies have shown the close metabolic interdependence between carbohydrates and lipids $[9,10]$. Plasma insulin is also a strong correlate of plasma lipids, especially HDL-cholesterol and triglyceride [11-14], and it is now well established that plasma insulin levels are generally higher in subjects with Type 2 (non-insulin-dependent) diabetes compared to non-diabetic subjects
[15]. The aim of the present work, based on the data of the Paris Prospective Study, was to analyse further the respective and interactive roles of insulin, glucose tolerance, cholesterol and triglyceride plasma levels on the risk of CHD mortality.

\section{Subjects and methods}

Subjects selected in the present analysis were drawn from the population of the Paris Prospective Study. The general aims, detailed methodology and population characteristics of the Paris Prospective Study have been previously described $[7,16]$ and only relevant data will be summarised here. The first follow-up examination involved 7,038 male employees of the Paris Civil Service, aged 43-54 years, without any cardiovascular disease diagnosed at examination [8]. It included a $0-2 \mathrm{~h} 75 \mathrm{~g}$ oral glucose tolerance test with measurement of plasma insulin [17] and glucose levels [18] beside the major CHD risk factors (blood pressure, smoking habits, body mass index (weight $(\mathrm{kg}) /$ height $^{2}(\mathrm{~m})$ ), plasma cholesterol [19] and plasma triglyceride [20] levels). All deaths up to January 1st 1983 were counted (mean followup: 11 years). Deaths were systematically reported by the different administrative departments of the Paris Civil Service.

Complementary inquiries to families, practitioners or hospitals were organized to obtain information regarding the circumstances and causes of death. Coding was performed by a panel of physicians according to the International Classification of Diseases (8th revi- 
Table 1. Mean values (95 percent confidence limits) of coronary heart disease (CHD) mortality rates and CHD mortality risk factors according to degree of glucose tolerance

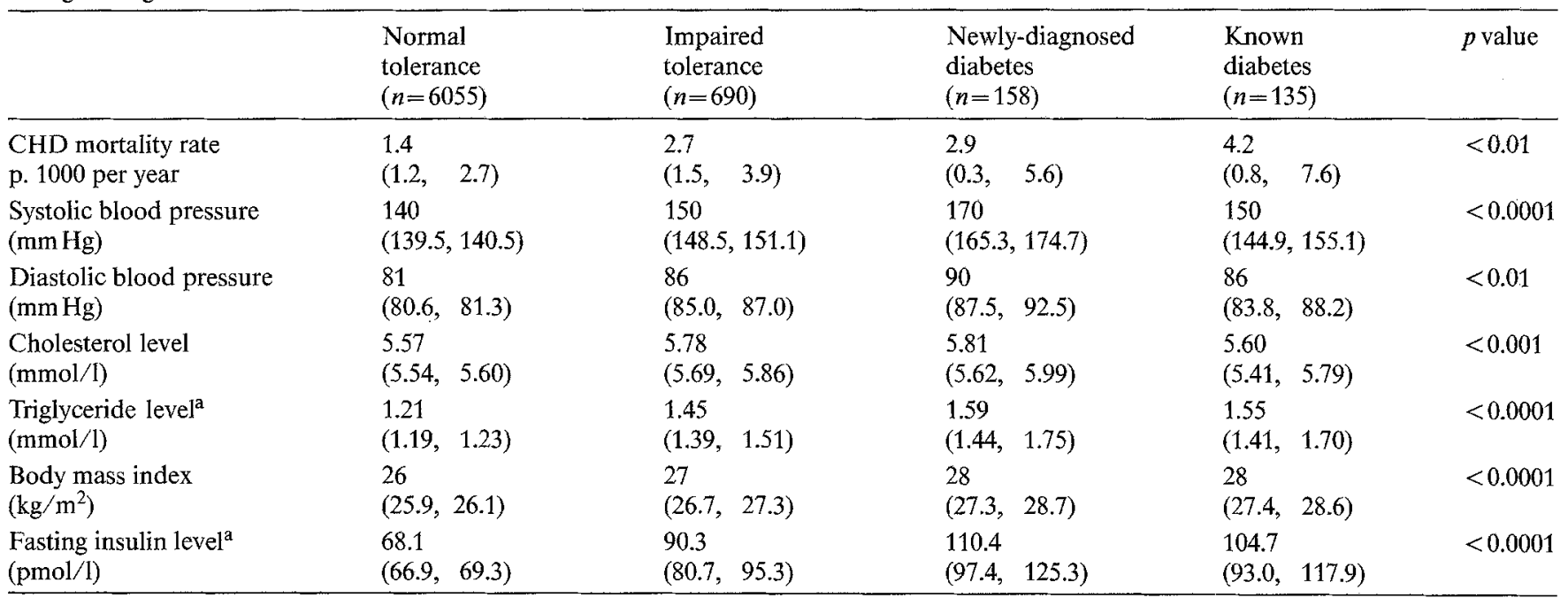

${ }^{a}$ Mean and mean \pm 2 SEM were computed in natural log values, then transformed into the original units $n=$ Number of patients studied

Table 2. Mean values ( $95 \%$ confidence limits) of baseline variables in subjects with abnormal glucose tolerance (impaired glucose tolerance or diabetes ${ }^{\mathrm{a}}$ ) by subsequent death from $\mathrm{CHD}$ : group $\mathrm{A}=\mathrm{CHD}$ death; group $\mathrm{B}=$ no CHD death or alive

\begin{tabular}{|c|c|c|c|c|c|}
\hline & $\begin{array}{l}\text { Group } \\
(n=26\end{array}$ & & $\begin{array}{l}\text { Group } \\
(n=91\end{array}$ & & $p$ value $^{\mathrm{b}}$ \\
\hline $\begin{array}{l}\text { Age } \\
\text { (years) }\end{array}$ & $\begin{array}{l}49.0 \\
(48.2\end{array}$ & 49.8) & $\begin{array}{l}48.6 \\
(48.5\end{array}$ & 48.7) & $>0.6$ \\
\hline $\begin{array}{l}\text { Systolic blood pressure } \\
(\mathrm{mm} \mathrm{Hg})\end{array}$ & $\begin{array}{l}161 \\
(151.2\end{array}$ & $170.8)$ & $\begin{array}{l}156 \\
(154.3\end{array}$ & $157.7)$ & $>0.4$ \\
\hline $\begin{array}{l}\text { Cigarettes } \\
\text { (number/day) }\end{array}$ & $\begin{array}{l}12 \\
(0\end{array}$ & 16) & $\begin{array}{l}9 \\
(0\end{array}$ & 10) & $>0.1$ \\
\hline $\begin{array}{l}\text { Cholesterol } \\
(\mathrm{mmol} / \mathrm{1})\end{array}$ & $\begin{array}{l}6.3 \\
6.0\end{array}$ & $6.6)$ & $\begin{array}{l}5.7 \\
(5.6\end{array}$ & $5.8)$ & $<0.02$ \\
\hline $\begin{array}{l}\text { Body mass index } \\
\left(\mathrm{kg} / \mathrm{m}^{2}\right)\end{array}$ & $\begin{array}{l}28 \\
(26.8\end{array}$ & 29.2) & $\begin{array}{l}27 \\
(26.7\end{array}$ & 27.3) & $>0.1$ \\
\hline $\begin{array}{l}\text { Triglyceride level } \\
(\mathrm{mmol} / 1)\end{array}$ & $\begin{array}{l}2.07 \\
(1.68\end{array}$ & $2.56)$ & $\begin{array}{l}1.47 \\
(1.42\end{array}$ & $1.53)$ & $<0.006$ \\
\hline $\begin{array}{l}\text { Fasting insulin level }{ }^{\mathrm{c}} \\
(\mathrm{pmol} / \mathrm{l})\end{array}$ & $\begin{array}{l}129 \\
(106\end{array}$ & 157) & $\begin{array}{l}93 \\
(89\end{array}$ & 98) & $<0.02$ \\
\hline $\begin{array}{l}2 \mathrm{~h} \text { insulin level } \\
(\mathrm{pmol} / \mathrm{l})\end{array}$ & $\begin{array}{l}595 \\
(484\end{array}$ & 731) & $\begin{array}{l}450 \\
(430\end{array}$ & 472) & $<0.02$ \\
\hline $\begin{array}{l}\text { Fasting glucose level } \\
(\mathrm{mmol} / \mathrm{l})\end{array}$ & $\begin{array}{l}6.8 \\
6.1\end{array}$ & $7.5)$ & $\begin{array}{l}6.5 \\
(6.4\end{array}$ & 6.6) & $>0.3$ \\
\hline $\begin{array}{l}2 \mathrm{~h} \text { glucose level } \\
(\mathrm{mmol} / \mathrm{l})\end{array}$ & $\begin{array}{l}9.9 \\
(9.4\end{array}$ & 10.4) & $\begin{array}{l}9.6 \\
(9.5,\end{array}$ & 9.7) & $>0.5$ \\
\hline
\end{tabular}

a 1980 WHO classification; ${ }^{b}$ Cox survival analysis; ${ }^{c}$ Mean and mean \pm 2 SEM were computed in natural $\log$ values, then transformed into the original units

$n=$ Number of patients studied

sion); in the present analysis, only deaths caused by CHD to a large extent (410.0-414.9:myocardial infarction; 795.0:sudden death; 782.0-782.9, 427.0, 427.1, 519.1: heart failure) were considered.

Among the 7,038 men attending the first follow-up examination, 135 were already known diabetics, and the remaining were classified from the $0-2 \mathrm{~h}$ oral glucose tolerance test results (WHO criteria 1980 [2]) into a group with normal glucose tolerance $(n=6,055)$, a group with impaired glucose tolerance (IGT, $n=690$ ), and a group with newly-diagnosed diabetes $(n=158)$. Subjects with impaired glucose tolerance or known or newly-diagnosed diabetes were selected for the present analysis and grouped together in an 'abnormal glucose tolerance' group. Those with missing values for a variable used in analyses were excluded. Insulin-treated diabetic subjects $(n=10)$ were also excluded, since the presence of exogenous insulin interfered with the interpretation of plasma insulin values. Altogether, 943 subjects with 'abnormal glucose tolerance' were considered for the present analysis, among whom 26 died from CHD during the follow-up.

Because of the narrow range of age of the population, no adjustment for age was made in univariate analyses. However, in the multivariate analysis using the Cox regression model [21] - BMDP 1981, statistical software $\mathrm{P} 2 \mathrm{~L}$-, age was systematically introduced into the equation.

\section{Results}

\section{A) Rationale for the grouping together of subjects with impaired glucose tolerance or diabetes}

Before proceeding to the analysis of CHD risk factors in subjects with impaired glucose tolerance or diabetes, the question was raised as whether they could be considered as a single group in regard to CHD risk.

It appeared that CHD mortality rates were nearly identical for subjects with IGT and subjects with newlydiagnosed diabetes (Table 1 ), the higher mortality rate for diabetic subjects as a whole deriving from the high mortality rate observed for subjects with known diabetes. In terms of specific causes of death (myocardial infarction, sudden death, heart failure), only mortality rates for sudden death differed significantly with the degree of glucose tolerance. The annual mortality rate for sudden death was 1.6 per 1,000 for subjects with IGT (12 deaths), in comparison to 0.8 per 1,000 for subjects with normal glucose tolerance ( 51 deaths), and to 2.3 per 1,000 (4 deaths) and 2.1 per 1,000 (3 deaths) in newly-diagnosed and known diabetic subjects respectively. In terms of level of CHD risk factors, again those 

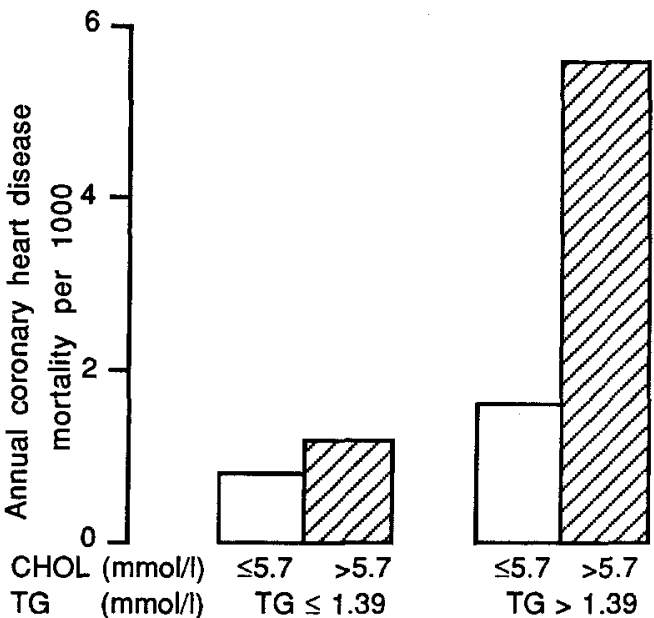

Fig. 1. Mean annual coronary heart disease (CHD) mortality rates by triglyceride level (TG) - below and above the median of the distribution: $1.39 \mathrm{mmol} / 1$ and by cholesterol level (CHOL) - below ( $\square$ ) and

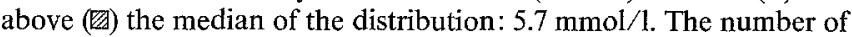
deaths observed in these four groups was $3,2,3$ and 18 from left to right

for subjects with IGT were generally closer to the levels of subjects with diabetes than to the levels of subjects with normal glucose tolerance (Table 1).

Thus, the group of subjects with either impaired glucose tolerance or diabetes appeared relatively homogeneous in regard to the risk of CHD.

\section{B) Cardiovascular risk factors in subjects with abnormal glucose tolerance}

The mean plasma levels of potential risk factors of CHD death in subjects with abnormal glucose tolerance $(n=943)$ were compared between those who died of CHD (group A, $n=26$ ) and those who did not (group B, $n=917$ ) (Table 2). Only plasma triglyceride, plasma cholesterol and plasma insulin levels (fasting and 2-h post-load) were significantly higher in group A. Whereas the correlation coefficient between cholesterol and insulin levels was rather weak $(\mathrm{r}=-0.05$ with fasting insulin, $p>0.1 ; \mathrm{r}=-0.02$ with 2 -h post-load insulin, $p>0.5$ ), it was stronger between triglyceride and cholesterol levels $(\mathrm{r}=0.36, p<0.0001)$, and between triglyceride and insulin levels $(r=0.28$ with fasting insulin, $p<0.0001 ; \quad \mathrm{r}=0.18$ with 2 -h post-load insulin, $p<0.0001)$. When grossly adjusting for triglyceride level (in two equal-sized groups, below and above the median of the triglyceride distribution: $1.39 \mathrm{mmol} / 1)$, both cholesterol and insulin levels seemed to retain a predictive value on subsequent CHD death for subjects in the upper half of triglyceride distribution (Figs.1 and 2). However, the multivariate analysis showed that the only variable significantly associated with CHD mortality risk was triglyceridaemia, independently of all other variables indicated in Table 2 . The fit of the model was not significantly improved by the introduction of cholesterol $\left(\chi^{2}=1.89,1 \mathrm{df}\right)$ or insulin, either fasting or 2 -h post-load $\left(\chi^{2}=2.79,1 \mathrm{df}\right)$, or both $\left(\chi^{2}=5.49,2 \mathrm{df}\right)$.

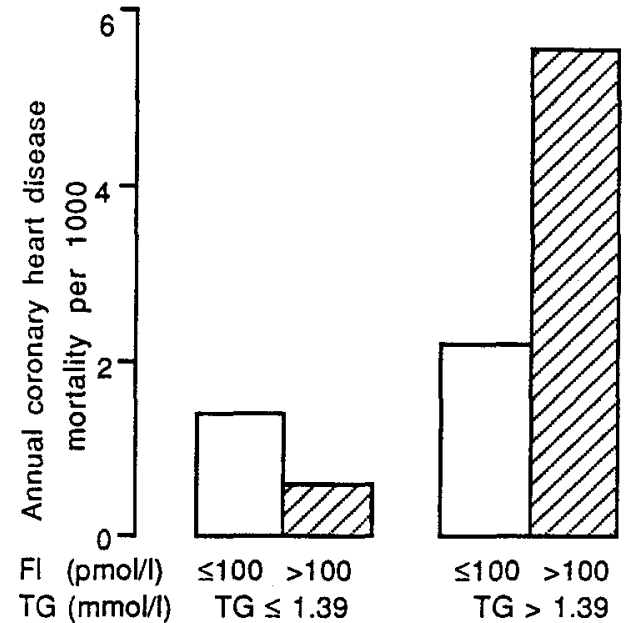

Fig. 2. Mean annual CHD mortality rates by triglyceride level (TG) below and above the median of the distribution: $1.39 \mathrm{mmol} / 1$ - and by fasting insulin level (FI) below ( $\square$ ) and above (㔰) the median of the distribution: $100 \mathrm{pmol} / 1$. The number of deaths observed in these four groups was $4,1,5$ and 16 from left to right

Other potential confounding variables, not directly related to cardiovascular risk but known to increase triglyceride plasma level, were ascertained in the 943 subjects. At the time when triglyceride plasma level was measured, antihypertensive treatment was used regularly by 44 subjects, 2 in group A, 42 in group B $(p>0.5)$. Liver condition had been assessed clinically at entry, and 107 subjects had signs of alcoholic intoxication, 4 in group A, 103 in group B ( $p>0.5)$. Therefore, it was unlikely that the cardiovascular risk associated with high triglyceride plasma levels could be mediated through those parameters.

Thus, hypertriglyceridaemia appeared as a major risk factor of CHD death in subjects with abnormal glucose tolerance. Indeed, as shown in Figure 3, the distribution of triglyceride level in group A was clearly shifted to the right compared to the distribution in group B. Most of the subjects in group A (73\%) had a plasma triglyceride level over $1.5 \mathrm{mmol} / 1$, whereas plasma triglyceride level was below $1.5 \mathrm{mmol} / 1$ for $56 \%$ of the subjects in group B. The relative risk of subsequent CHD death for subjects with a triglyceride level over $1.5 \mathrm{mmol} / 1$ was $3.28(p<0.01)$.

\section{Discussion}

The present analysis of the Paris Prospective Study emphasizes the relation of dyslipidaemia and the occurrence of coronary heart disease in subjects with impaired glucose tolerance or diabetes. In this particular population, which is probably in part heterogeneous, but shares common metabolic abnormalities and an increased risk for CHD [22-24], an elevated plasma triglyceride level proved to be the strongest predictor of CHD death. The lack of power of the analysis, due to the relatively small number of deaths, may have concealed an independent contribution of insulin and cholesterol plasma levels to 


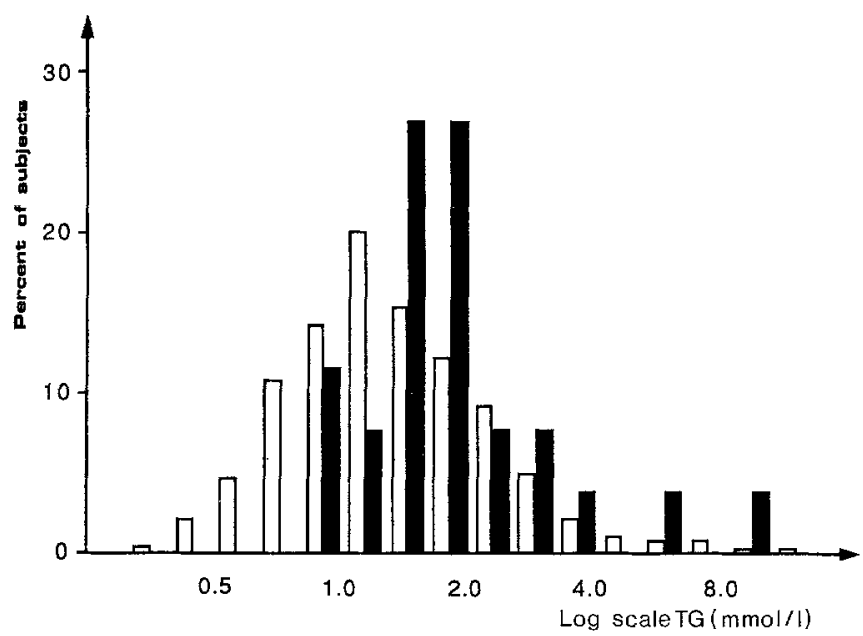

Fig.3. Distribution of serum triglyceride level by subsequent death from CHD or not. Closed bars ( $\square$ ): group A (CHD death, $n=26$ ); open bars $(\square)$ ): group B (no CHD death or alive, $n=917$ )

the prediction model, but the fact remains that triglyceride plasma level ranked markedly first in this model.

Though prospective studies in diabetic cohorts are scarce, the present analysis agrees well with the results of the Schwabing Study, where triglyceride plasma level appeared as the main lipid abnormality positively linked to the 5-year incidence of major vascular events in diabetic patients [25], and with the data of the WHO Multinational Study on the Complications of Diabetes [26].

In non-diabetic populations, the relationship between triglyceride plasma level and cardiovascular risk generally appears to be mediated through other metabolic abnormalities [27]. This statement also applies to the results of the global analysis of the Paris Prospective Study [7, 8]. However, there may be some particular metabolic situations where hypertriglyceridaemia is an independent marker of CHD risk [28]. For example, it has already been shown with the data of the Paris Prospective Study that plasma triglyceride level was an independent predictor of CHD mortality risk in subjects with a low plasma cholesterol level [29]. This predictive value could be due to the inverse relationship between triglyceride-rich lipoproteins and high-density lipoproteins [30,31], since high HDL levels have been shown to be associated with a lower cardiovascular risk [32].

Both high triglyceride levels and low HDL concentrations are typically found in non-insulin-dependent diabetes and impaired glucose tolerance [33-35]. This particular form of dyslipidaemia could be related to an impairment of insulin action, one of the key factors in the regulation of lipoproteins metabolism $[30,36]$, and accumulating evidence tends to make it a marker of insulin resistance [37-40]. It may possibly be a causal factor of coronary artery disease, by itself [41], or through the atherogenicity of VLDL catabolism remnants [42], or because of the enrichment of HDL particles with triglyceride rather than cholesterol, which could lower their capacity for cholesterol uptake and therefore deteriorate their antiatherogenic power [43]. Keeping in mind that insulinaemia was an independent risk factor of CHD death in the global analysis of the Paris Prospective Study [7, 8], and that CHD mortality risk was clearly higher in hyperinsulinaemic-hypertriglyceridaemic subjects with abnormal glucose tolerance (Fig. 2), the results of the present analysis support the hypothesis that the increased risk of coronary artery disease in subjects with abnormal glucose tolerance is due to the clustering of cardiovascular risk factors associated with insulin resistance [44-47].

The increase in CHD mortality risk with triglyceride plasma concentration in subjects with impaired glucose tolerance or diabetes awaits confirmation from other prospective studies. However, if it proves stable, such a dyslipidaemia should be sought in this population as a simple way of identifying those who are more "at risk" of coronary heart disease. Preventive interventions are still to be defined, but an appropriate guideline might be to reduce insulin resistance and/or to improve lipoprotein profile by way of diet, exercise, and possibly drugs [48-51].

Acknowledgements. This research was supported in part by a grant from the Ministry of Health to the Groupe d'Etude sur l'Epidemiologie de l'Athérosclérose which associates with INSERM and the Direction de l'Action Sociale, de l'Enfance et de la Santé de la Préfecture de Paris.

\section{References}

1. Garcia MJ, McNamara PM, Gordon T, Kannel WB (1974) Morbidity and mortality in diabetics in the Framingham population. Sixteen year follow-up study. Diabetes 23: 105-111

2. WHO Expert Committee on Diabetes Mellitus (1980) Second report. Technical report series 646 . WHO, Geneva

3. Vigorita VJ, Moore GW, Hutchins GM (1980) Absence of correlation between coronary arterial atherosclerosis and severity or duration of diabetes mellitus of adult onset. Am J Cardiol 46: $535-542$

4. Jarrett RJ, Shipley MJ (1988) Type 2 (non-insulin-dependent) diabetes mellitus and cardiovascular disease - putative association via common antecedents; further evidence from the Whitehall Study. Diabetologia 31: 737-740

5. Pyörälä K (1979) Relationship of glucose tolerance and plasma insulin to the incidence of coronary heart disease: results from two population studies in Finland. Diabetes Care 2: 131-141

6. Welborn TA, Wearne K (1979) Coronary heart disease incidence and cardiovascular mortality in Busselton with reference to glucose and insulin concentrations. Diabetes Care 2: 154-160

7. Ducimetière $P$, Eschwège $E$, Papoz L, Richard $J$, Claude JR, Rosselin GE (1980) Relationship of plasma insulin levels to the incidence of myocardial infarction and coronary heart disease mortality in a middle-aged population. Diabetologia 19: 205-210

8. Eschwège $\mathrm{E}$, Richard JL, Thibult $\mathrm{N}$, et al. (1985) Coronary heart disease mortality in relation with diabetes, blood glucose and plas$\mathrm{ma}$ insulin levels. The Paris Prospective Study ten years later. Horm Metabol Res Suppl Series 15: 41-56

9. Ganda OMP (1985) Pathogenesis of macrovascular disease including the influence of lipids. In: Marble A, Krall LP, Bradley AR, Christlieb AR, Soeldner JS (eds) Joslin's diabetes mellitus. Lea \& Febiger, Philadelphia, pp 217-250

10. Barrett-Connor E, Grundy SM, Holdbrook MJ (1982) Plasma lipids and diabetes mellitus in an adult community. Am $\mathrm{J}$ Epidemiol 115: 657-663

11. Saudek CD, Eder HA (1979) Lipid metabolism in diabetes mellitus. Am J Med 66: 843-852 
12. Orchard TJ, Becker DJ, Bates M, Kuller LH, Drash AL (1983) Plasma insulin and lipoprotein concentrations: an atherogenic association? Am J Epidemiol 118: 326-337

13. Zavaroni I, Dall'Aglio E, Alpi O et al. (1985) Evidence for an independent relationship between plasma insulin and concentration of high density lipoprotein cholesterol and triglyceride. Atherosclerosis 55: 259-266

14. Cambien F, Warnet $M$, Eschwège $E$, Richard JL, Rosselin G (1987) Body mass, blood pressure, glucose and lipids. Does plasma insulin explain their relationships? Arateriosclerosis 7: 197-202

15. Cahill GF Jr (1988) Beta-cell deficiency, insulin resistance, or both? N Engl J Med 318: 1268-1270

16. Ducimetière P, Richard JL, Claude JR (1981) Les cardiopathies ischémiques: incidence et facteurs de risque. L'Etude Prospective Parisienne. Editions INSERM, Paris, pp 9-21

17. Rosselin G, Assan R, Yalow RS, Berson SA (1966) Separation of antibody bound and unbound peptide hormone labelled with iodine 131 by talcum powder and precipitates silica. Nature 212: 355-357

18. Anonymous (1963) Methodologie Technicon Auto Analyser 'N' 2a, 2nd edn Dec. Technicon Ltd

19. Etienne G, Papin JP, Renault M (1963) Une méthode simple du dosage du cholestérol par voie automatique. Ann Biol Clin 21: 851-853

20. Claude JR, Corre F (1968) Considérations pratiques sur le dosage semi-automatique des triglycérides sériques par fluorométrie (méthode de Kiessler et Lederer). Comparaison avec la méthode manuelle colorimétrique de Van Handel et Zilversmit. Ann Biol Clin 26: 451-454

21. Cox DR (1972) Regression models and life tables (with discussion). J R Statist Soc B34: 187-220

22. Stamler J, Stamler R (1979) Asymptomatic hyperglycaemia and coronary heart disease. A series of papers by the International Collaborative Group based on studies in fifteen populations. Joint discussion. J Chron Dis 32: 829-837

23. Stern MP, Rosenthal M, Haffner SM (1985) A new concept of impaired glucose tolerance: relation to cardiovascular risk. Arteriosclerosis $5: 311-314$

24. Editorial (1980) Diabetes, hyperglycaemia and coronary heart disease. Lancet I: 346

25. Janka HU (1985) Five-year incidence of major macrovascular complications in diabetes mellitus. Horm Metabol Res Suppl Series 15: 15-19

26. West KM, Ahuja MMS, Bennett PH, et al. (1983) The role of circulating glucose and triglyceride concentrations and their interaction with other risk factors as determinants of arterial disease in nine diabetic population samples from the WHO Multinational Study. Diabetes Care 6: 361-369

27. Hulley SB, Rosenman RH, Bawol RD, Brand RJ (1980) Epidemiology as a guide to clinical decisions. The association between triglyceride and coronary heart disease. N Engl J Med 302:1383-1418

28. Castelli WP (1986) The triglyceride issue: a view from Framinghàm. Am Heart J 112: 432-437

29. Cambien F, Jacqueson A, Richard JL, Warnet JM, Ducimetière $P$, Claude JR (1986) Is the level of serum triglyceride a significant predictor of coronary death in "normocholesterolemic" subjects? The Paris Prospective Study. Am J Epidemiol 124: 624-632

30. Nikkilä EA (1978) Metabolic and endocrine control of plasma high density lipoprotein concentration. Relation to catabolism of triglyceride-rich lipoproteins. In: Gotto AM, Miller NE, Oliver MF (eds) High density lipoproteins and atherosclerosis. Elsevier, Amsterdam, pp 177-192

31. Albrink MJ, Krauss RM, Lindgren FT (1980) Intercorrelations among plasma high density lipoprotein, obesity and triglycerides in a normal population. Lipids 15: 668-676

32. Gordon T, Castelli WP, Hjortland MC, et al. (1977) High density lipoprotein as a protective factor against coronary heart disease. Am J Med 62: 707-714
33. Abrams JJ, Ginsberg H, Grundy SM (1982) Metabolism of cholesterol and plasma triglycerides in non-ketotic diabetes mellitus. Diabetes 31: $903-910$

34. Uusitupa M, Siitonen O, Voutilainen E, et al. (1986) Serum lipids and lipoproteins in newly-diagnosed non-insulin-dependent (Type II) diabetic patients with special reference to factors influencing HDL-cholesterol and triglyceride levels. Diabetes Care 9: $17-22$

35. Steiner G (1986) Hypertriglyceridemia and carbohydrate intolerance: interrelations and therapeutic implications. Am J Cardiol 57: $27 \mathrm{G}-30 \mathrm{G}$

36. Fossati $P$, Romon-Rousseaux M (1987) Insulin and HDL cholesterol metabolism. Diabete Metabolisme (Paris) 13:390-394

37. Bernstein RM, Davis BM, Olefsky JM, Reaven GM (1978) Hepatic insulin responsiveness in patients with endogenous hypertriglyceridaemia. Diabetologia 14: 249-253

38. Stalder M, Pometta D, Suentam A (1981) Relationship between plasma insulin levels and high density lipoprotein cholesterol levels in healthy men. Diabetologia 21: 544-548

39. Laakso M, Pyörälä K, Voutilainen E, Marniemi J (1987) Plasma insulin, serum lipids and lipoproteins in middle-aged non-insulindependent diabetic and non-diabetic subjects. Am J Epidemiol 125: 611-621

40. Reaven GM, Chen YDI (1988) Role of insulin in regulation of lipoprotein metabolism in diabetes. Diabetes Metabol Rev 4: 639-652

41. Bates SR, Murphy PL, Feng Z, Kanazawa T, Getz GS (1984) Very low density lipoproteins promote triglyceride accumulation in macrophages. Arteriosclerosis 4: 103-114

42. Steiner G, Vranic M (1982) Hyperinsulinemia and hypertriglyceridemia, a vicious cycle with atherogenic potential. Intern J Obesity 6 [Suppl 1]: 117-124

43. Reaven GM, Greenfeld MS (1981) Diabetes hypertriglyceridemia. Evidence for three clinical syndromes. Diabetes 30 [Suppl 2]: 66-75

44. Reaven GM (1988) Role of insulin resistance in human disease. Diabetes 37: 1595-1607

45. Colwell JA, Winocour PD, Lopes-Virella M, Halushka PV (1983) New concepts about the pathogenesis of atherosclerosis in diabetes mellitus. Am J Med 75:67-80

46. Schwandt P (1985) Very low density lipoproteins in Type II diabetes mellitus and risk of atherosclerosis. Horm Metabol Res Suppl Series 15: 83-87

47. Pyörälä K, Uusitupa M, Laakso M, Siitonen O, Niskanen L, Rönnemaa T (1987) Macrovascular complications in relation to hyperinsulinaemia in non-insulin-dependent diabetes mellitus. Diabete Metabolisme (Paris) 13: 345-349

48. Thomas BJ, Jarrett JR, Keen H, Ruskin JH (1982) Relation of habitual diet to fasting plasma insulin concentration and the insulin response to oral glucose. Hum Nutr Clin Nutr 36c: 49-56

49. Pedersen O, Beck-Nielsen H, Heding L (1980) Increased insulin receptors after exercise in patients with insulin dependent diabetes mellitus. N Engl J Med 302: 886-892

50. Gordon DJ, Witztum JL, Hunninghake D (1983) Habitual physical activity and high density lipoprotein in men with primary hypercholesterolemia. The Lipid Research Clinic Coronary Primary Prevention Trial. Circulation 67: 512-520

51. Garg A, Grundy SM (1988) Lovastatin for lowering cholesterol levels in non-insulin-dependent diabetes mellitus. N Engl J Med 318: 81-86

Received: 25 January 1989

and in revised form: 14 March 1989

Dr. A. Fontbonne

INSERM Unité 21

16 Avenue Paul Vaillant-Couturier

F-94807 Villejuif

France 